\title{
Contents
}

Acknowledgments vii

1 No Place Like Home 3

2 The Chaco Prophet 25

3 The Plains Prophet 60

4 Shamans and Wives 80

5 Shamans and Spies $\quad$ IIO

6 Wizards and Ghosts $\quad$ I4I

7 Vulnerability in American Heartlands $\quad 172$

Notes 195

References 203

Index 22I 


\section{No Place Like Home}

The place in Isoso, Bolivia, where I can turn up unexpectedly at three in the morning and receive a hug and a bed and leave days later with tears on all sides lost, several years ago, its person of central anthropological interest. This was a shaman, quite a renowned one in the region. He managed to his eventual regret to attract the attention of so many scientists and agents of development that eventually a laboratory was built around him which became, in a way, his sarcophagus.

The people to whom I now go back are women and children: his wife, her mother and sister, his daughters, and their children. Over the years I have experienced a divide between what brings me back to Isoso-these women, and a few others in two other villages and a small nearby town - and what originally brought me to Isoso: men, principally that shaman but also a second shaman in another village and other men who occupied leadership roles in Isoso in externally funded development projects there around the turn of the twenty-first century. For about a decade between 2003 and 2013 I didn't know how to write or even to think about this disjuncture, at least not intellectually, though I knew how it felt emotionally: like a sham. I had profound sentiments about Isoso and people there that did not in any way animate or inform my analytic work as an anthropologist. Visits back felt at once necessary and silly: necessary to fulfill personal pledges and commitments but silly from a research point of view as the questions I most wanted to ask (who had gotten married and who had split up, who had had babies, who was going to school and who was working, who had been ill, who had died) spoke to no problems of 
general anthropological interest as I then conceived it, and addressing problems of general anthropological interest only seemed possible by asking questions I found ever less compelling of people with whom I'd never felt at ease.

The women I go back to in Isoso are the women who cared for me during my fieldwork. They cooked for me, which in Isoso is no small task. Water has to be hauled from hand pumps, firewood gathered, plant food harvested, and animal food butchered. Some of the women made up beds for me, and others found candles so I could see at night or lent buckets so I could bathe and wash my clothes. They made small talk with me, at first just inquiring how I'd slept, what I'd dreamt about, the way I might be feeling (lonesome), but over time asking more detailed questions about my family, my relationships, my house and my work, and sharing with me stories from the offhand (births of puppies, piglets, and chicks) to the richly elaborated (whose marriages were fraught, and why). All of this interaction was in between my "real" work: awkward censuses, stilted interviews, slightly lost wanderings-about.

I was acutely aware that what they were doing for me was hard effort of both the physical and emotional kind. It made my anthropological research possible but would be invisible in the results, aside from the customary lines of gratitude in an acknowledgments section of a doctoral thesis or eventual book. By the end of my fieldwork in the late 1990s, and certainly in the course of the years that have elapsed since, I had spent vastly more time in the company of, and in conversation with, Isoseño women than with the Isoseño men who were the central actors in the traditional medicine and environmental protection projects that had motivated my first fieldwork in Isoso. Those projects themselves, like my fieldwork investigations of them, came by contrast to appear to me as artificial forms of make-believe.

I arrived at the argument of this book circuitously. In the years between my doctoral field research and its writing, I did a bit of ethnohistorical research; I reread all of the fourteen original $\mathrm{Oz}$ books and quite a bit of the biographical literature on their author, L. Frank Baum; I attempted new fieldwork in Paraguay. Those disparate efforts all bear conjoined fruit here. But it was reading theory new to me-in disability studies and in feminism - that helped me organize a set of inchoate themes into a case. My first trip to Isoso was in 1997, and my most recent was in 2019. On a visit in 2013 I took with me philosopher Eva Feder Kittay's 1999 book Love's Labour: Essays on Women, Equality, and Dependency. She gave a name and a profound theoretical armature to what surrounded me constantly in Isoso and about which I had never been able to write: "dependency work." I began to have an uncomfortable-making understanding of my previous classification of so many of the activities and interactions that made my time in Isoso possible as unworthy of thoughtful note. Most especially, I began to reassess the way in which intellectual judgement was belied by my own daily practice: often finding false and boring the ostensible objects of my

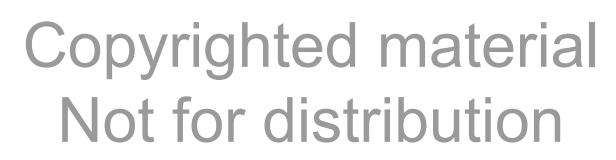


investigative interest whilst spending most of my actual time in the field in interactions that felt vital and genuine but not articulable in disciplinary terms.

It is of course the case that anthropology has always cared about kinship, and so the questions about births and deaths, mothers and children and marriages, that compel me in Isoso would doubtless have compelled my colleagues if I'd chosen to write about those questions. There was a time when closely annotated kinship diagrams would have been pored over by anthropologist readers of my work. However, the elegance and aridity of such analyses can serve to paper over vulnerability in the domains where it looms largest. While there has recently been an "affective turn" in anthropology (Rutherford 2016), including lowland South American anthropology (Surralles 2009), it is motivated by theorists like Brian Massumi (2002) and argues over the "ontological turn" inspired by Eduardo Viveiros de Castro (1998) and does not draw, as I do, on feminist scholarship.

\section{PLAN OF BOOK}

My original doctoral fieldwork investigated two projects in Isoso that were funded by Western governments during the 1990s. At the time, these projects seemed exciting heralds of the coming of a multicultural postextractive green future. In retrospect, they look like tiny final arabesques of the crumbling Cold War order. For detailed descriptions of these two projects, interested readers are encouraged to consult Lowrey (2003) and Lowrey (2008a). The first was a plan to involve Isoseño people, by virtue of their being indigenous to the land in question, in the management of a very large new Bolivian national park, established in 1995: the Parque Nacional Kaa-Iyaa del Gran Chaco. The second, which was a major focus of my fieldwork, was a plan to involve Isoseño shamans in an attempt to commercialize traditional medicine. Both were explicitly framed as promoting the autonomy and self-sufficiency of Isoseño people. Both did real damage to Isoso. In large part, this book grew out of my efforts to go back in time and sideways in imagination in order to understand why these projects (and projects like them) ever seemed like good ideas.

This first chapter ("No Place Like Home") will introduce my primary field site, Isoso, which is a community of 15,000 Guaraní-speaking people living in twentythree villages strung along the Parapetí River in the Bolivian Chaco. The South American Gran Chaco shares many geographic, historical, political, and cultural features with the North American Great Plains, something that will be a recurrent theme in the book. While Pan-American and hemispheric indigenous studies often reiterate the important point that the Americas are interrelated, this book draws out some undernoticed parallel histories and geographies in this pair of North and South American heartlands.

\section{Copyrighted material Not for distribution}


Chapter 2 ("The Chaco Prophet") goes back to the late nineteenth century and treats a prophetic movement among Bolivian Guaraní people in the Gran Chaco that ended in a massacre at a site called Kuruyuki in 1892 . I systematically go through the authoritative historical account of that movement, which was published in 1972 by Bolivian historian and folklorist Hernando Sanabria Fernández. I show how his version of Guaraní history and particularly his figuring of defiance, autonomy, and masculinity as key features of Guaraníness created certain kinds of opportunities for Guaraní revitalization in the 1980 s and 1990 os but foreclosed others in ways that have had unfortunate consequences for Guaraní political mobilization. Sanabria's account also seriously misrepresents the historical record of what late nineteenthcentury Guaraní people said at the time about their intentions, which his book casts as having been exclusively violent and martial. The fragmentary direct testimony that exists of nineteenth-century Guaraní people articulating their own aims bespeaks concerns for families and relationships: longing for connection with deceased kin and for kinder relations with settler Bolivian authorities.

Chapter 3 ("The Plains Prophet") documents my original research, uncovering how profoundly Sanabria's account was influenced by the scholarly and popular literature on North American Plains Indians, the Old West, the Ghost Dance movement, and the massacre at Wounded Knee. Using disability theory as a theoretical lens, I return to that North American literature and find in it pervasive reference to debility and vulnerability. The historical and anthropological literature on "revitalization movements" looks very different and much less persuasive in light of recent insights from disability scholars. I suggest that much of the twentieth-century analysis of revitalization movements that dwells on fantasized invulnerability in the face of modernity attributed to traditional peoples might be a sort of anxious projection on the part of modern Western analysts. The Ghost Dance and Wounded Knee are the canonical cases for this literature, and so I return to several classic and influential studies to demonstrate exactly how this process has worked and been propagated from that "original." I suggest that in both the Bolivian case discussed in the chapter 2 and the American case discussed in this chapter, settler interlocutors in the past and present have misunderstood or refused to acknowledge indigenous overtures relating to dependence and mutuality, interpreting them instead as deceptive subterfuge masking violent, hostile intent.

Chapter 4 ("Shamans and Wives") focuses on my fieldwork with two Isoseño shamans, both associated with the laboratory of traditional medicine. I describe the families and households I know best in Isoso and argue that the importance of family life has gone underanalyzed in the extent literature on Amerindian shamanism. Much anthropological analysis of shamanism has treated it as directly corollary to traditionally masculinist domains in settler society, supposing shamanism to be

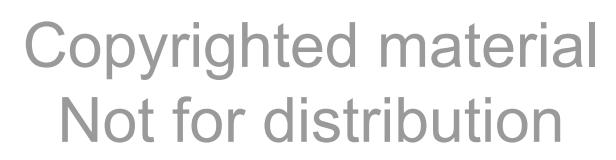


either esoteric (akin to a priesthood) or technocratic (akin to science or medicine). Arguing from my own ethnographic evidence, I suggest instead that shamanism is a practice of allyship in the feminist sense, in which shamans commit to long-term solidarity with fellow community members in difficulty, relationships in which their wives and families also play key roles. It is precisely the masculinist misunderstanding of shamanism that led to the externally funded creation of the laboratory of traditional medicine, which was a disappointment to the outside funders and a cataclysmic disaster for the Isoseño people most closely involved with it.

Chapter 5 ("Shamans and Spies") opens with the many dark conspiracy theories the Isoseño people whom I knew best had about the laboratory of traditional medicine-suppositions about which I was for many years dismissive. However, in researching the ethnobotanical justification for its funding and the propositions made in it about what shamanism is and what shamans know and do, I track a path back from South American shamans to a set of North American, Cold War operators. The origins and extant edifice of much work on shamanism and ethnobotany and, especially, that work's combined claims of scientific accomplishment and macho swashbuckling, deserve almost infinitely more critical scrutiny than they have hitherto received in anthropology. By critically examining the backstory of "father of ethnobotany" Richard Evans Schultes and his acolytes and popularizers, I am able to show just how sinister and dishonest is the projection of an infinite power to heal settler ills precisely on to some of global modernity's most vulnerable colonial subjects: indigenous people and, particularly, lowland South American Indians.

Chapter 6 ("Wizards and Ghosts") contrasts two forms of imaginative narrative about power and debility: one drawn from US children's literature, the other from lowland South American myth. In I891, nearly a decade before Baum began the beloved and heartwarming $\mathrm{Oz}$ series, he published a heartless newspaper editorial about, of all things, the massacre at Wounded Knee. It has in recent years become notorious. Baum's defenders suggest it was a clumsy satire. What interests me is its bad-faith attempt to simultaneously lament and glory in Indian vulnerability and the strenuous implicit claims about white power and invulnerability necessary to that stance. From there I look again at the perennially popular Oz books and find in them an astonishing proliferation of themes of disability, vulnerability, disintegration, dismemberment, and radical social dependency. All of this obsessive elaboration of forbidden topics is, I argue, permissible and plausibly deniable because the $\mathrm{Oz}$ books are "just pretend" and meant for children. I join to this analysis a contrasting Amerindian case. Here I consider a special class of lowland South American indigenous narratives described in published accounts by renowned French anthropologist Anne-Christine Taylor. Taylor writes about Shuar stories that involve extremely powerful supernatural beings that can be encountered by humans only under unique

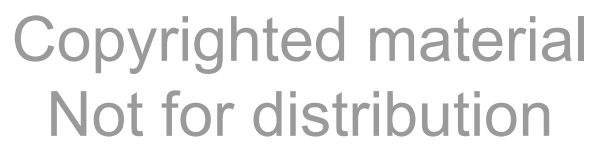


circumstances. The outcomes of these encounters sometimes confer dangerous personal power (usually on men) but, more often, produce debilities (usually on women and children), recuperation from which requires the assistance of close kin. In the settler case, disability and dependence can only be considered in the safe confines of children's fantasy; in the Amerindian case, heightened personal power is unusual (and suspect), and relational vulnerability is the ordinary order of things.

Chapter 7 ("Vulnerability in American Heartlands") concludes by demonstrating that the issues at play in the book are not inevitably about "settlers versus Indians" but most fundamentally about the historical self-fashioning of modernity in the Americas. I use the case of Mennonite settler colonies now adjacent to the indigenous communities with which I have worked in both the Bolivian and Paraguayan Chaco. Many Mennonite colonies in South America are visually anachronistic, with women in flowered dresses and men in overalls traveling by horse-drawn buggies and living in clapboard farmhouses abutted by picturesque windmills. Mennonites confound any neat categorization that aligns the "West" to the "Rest" as "settlers" to "Indians" or as "modern" to "traditional." Specifically, they confound assumptions about settler commitments to autonomy and individualism as being monolithic. Mennonite theology is marked by its orientation to salvation in community. Migrations from their origins in the borderlands between Germany and Holland, first to Prussia, then to Czarist Russia, then to Canada, and later to Latin America have always been prompted by encroaching modernity. Obligations to perform military service as a universal duty of citizenship (Mennonites are pacifist), to enroll their children in national-language schools (Mennonites speak low German at home, and their schooling is in high German), or to participate in state-run collectivist agrarian schemes (Mennonites organize their own farming collectives) have inspired Mennonites to seek out special relationships in a series of new countries where their special status privileges will be recognized and protected. Paraguay and Bolivia allowed Mennonites to settle during the twentieth century under special terms precisely in order to civilize their "savage" hinterlands; they were permitted their old-fashioned ways as, ironically, agents of modernization. Now, however, these protections are being stripped away as Bolivia and Paraguay consolidate their own achieved modernity as states that have no tolerance for vulnerable, dependent citizens, be they indigenous or settler.

\section{THEORETICAL FRAMEWORK}

Feminist philosopher Eva Feder Kittay's work on dependency had a profound influence on the writing of this book, and the analysis offered in it is also indebted to recent work in disability studies, which is treated in detail in several different

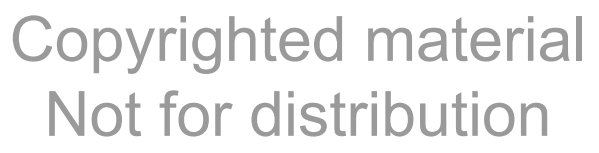


chapters. However, the arguments of the book also draw from a much older scholarly tradition. I have found it useful to employ a distinction first made by legal historian Henry Sumner Maine (I86I) between "status" and "contract" societies. Maine described a progressive shift in which Western societies moved "from status to contract," that is, from being organized by status relations toward being organized by contract relations. Non-Western societies, such as Amerindian societies, organized around "status" are treated in his framework as not just different but primitive, archaic. Anthropologists quite rightly find this hierarchized archaicizing untenable. Nevertheless, Maine's typology is useful in other ways.

Status societies are organized around implicit roles assigned by status attributes: sex, race, religion, class. People's recruitment to these roles is involuntary such that "duty" is highly socially valued-in other words, fulfilling the expectations for the role in which one finds oneself, willy-nilly. Contract societies are organized around explicit contracts arrived at by individuals. People's recruitment to these contracts is voluntary such that "choice" is highly socially valued — that is, identifying one's own preferences and proclivities and efficiently forming and severing contractual relations on their basis.

What interests me about Maine's distinction is that societies organized around status recognize (and even enforce) dependence and debility quite explicitly, while societies organized around contract reject, deny, and ignore dependence and debility, being explicit instead (again, often forcibly) on the themes of independence and autonomy. The downsides to status-organized societies are legion and have been exhaustively exemplified in the course of human history (patriarchy, slavery, and feudalism are all status-organized social systems). The downsides to contractorganized societies have only begun to be grasped during the past couple of centuries. One response-in Western and non-Western societies alike-has been what I will call a "flight from contract." This phenomenon (variously described and labeled) has been noted by others, usually disparagingly. I argue that the flight from contract is both inevitable —and inevitably disparaged — because it is a response to the pervasive, inevitable presence of human dependency and debility in societies ever more ill organized to deal with (or, to put it another way, ever more unwilling to even recognize) those features of human existence.

\section{DOMESTIC LANGUAGES OF DOUBT}

The book is in some respects predicated on commonplace anthropological formulations of compare and contrast: Western to Amerindian, contract to status. Such pairings can be quite illuminating, but at their most exciting they are almost always overdrawn: primitive versus modern, cold versus hot, multinaturalism

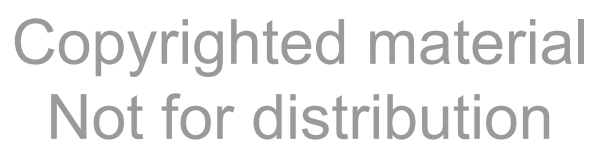


versus multiculturalism, purity versus hybridity, to give some of the most familiar examples. The modes of description and argumentation predicated on such contrasts are too often written and spoken in a mode that presumes skepticism only exists for theory-minded analysts while the average Western or Amerindian Joe, the average feudal or modern Jane, has lived and died possessed of no domestic language of doubt.

Paying attention to what people find dubious makes it far more difficult to make confident, overdrawn assertions about them and makes stark cultural and temporal divides begin to look permeable. Dependence and disability, on the one hand, and autonomy and "super-ability," on the other, are subjected to considerable culturally specific questioning while also being present in all the times and places under consideration. Thus this entire project is also animated by an interest in returning anthropology to the consideration of what might be human universals. Disability scholarship has been convincingly insistent about vulnerability, dependency, and frailty counting among these. Claims about human universals have fallen very far out of fashion in sociocultural anthropology in recent decades (while proliferating lamentably in what used to be called sociobiology and what is now known in evolutionary psychology). This fall from fashion-which coincided rather precisely with the emergence of feminist scholarship after the i96os and the universal challenge it presented to anthropology_relates to, and helps to explain, my own initial experiences as a novice fieldworker setting out at the tail end of the twentieth century and my previous sense that there was nothing of anthropological interest about the dependency work-mostly women's work-that surrounded me in the field and created the conditions of possibility for my being there. Kittay's work on the profound resistance in modern Western ontologies to considering dependency has upended my view of my own society but has also helped me to understand what (and here Freud helps too) was for me coded, in classic dreamwork fashion, as the parts "not worth telling about" when I was living in a society different from my own.

\section{PARTIAL ANTECEDENTS: "DEPENDENCY THEORY" \\ AND THE "ROMANCE OF RESISTANCE"}

When describing this book to others as I was writing it, I sometimes was asked if I had thought about the implications of using disability theory when the subjects of my research are indigenous people. The question illuminates perfectly a point disability theorists have made: that disability is an ur-category of stigma. These interlocutors were warily asking if I had realized the insult I was directing at indigenous people by implying they were either themselves disabled or that they had anything significant in common with disabled people.

\section{Copyrighted material Not for distribution}


My interlocutors' question makes clear that the directionality of potential insult in the contemporary context is one-way. In the nineteenth century (which is where the next chapter will begin), this directionality of insult was frequently reversed. People with disabilities were at pains to prove they were not like "savages." Douglas Baynton (1996) has written about how one of the resistances to adopting American Sign Language during the nineteenth century was the fact that Plains Indians had developed a sign language lingua franca for use across Plains indigenous languages. ${ }^{1}$ At a time when disability was sometimes supposed to result from archaic biological "survivals" unexpectedly resurfacing in offspring, white American families didn't want their hearing impaired children imitating "primitives."

We don't worry anymore about primitivity but we still do about disability, so the stigma of being charged with the former has mostly disappeared while the stigma of the latter remains strong. If anything, it has become all the stronger for being the rump-stigma against which other categories have proven themselves immune and therefore deserving of deliverance—race, gender, sexuality—as Baynton, again, has shown in a key essay (200I). Liberation movements around these categories have specifically insisted that black people, women, and gay people are not "less able," are not "sick," but are "normal" and "healthy." Similarly, Nancy Fraser and Linda Gordon have documented how across the same late modern period the scope of "dependency" has narrowed and become increasingly stigmatized: many racialized and gendered forms of dependency have been abolished, such that "all dependency is suspect, and independence is enjoined upon everyone" (1994: 324).

What can follow from this discussion is the good and important point that all such categories are social constructions: society "primitivizes," "indigenizes," or "disables" people. You can't be a primitive except relative to a pseudoscientific theory of social evolution; you can't be indigenous without colonialism; you can't be disabled except in a social and infrastructural context constructed to accommodate certain capabilities and exclude others (Oliver 2013). Anthropology has even had a large literature on "dependency theory," understood in this sense: a politicized state of affairs in which some world regions are forced into relations of dependence on other world regions (Gunder Frank 1967; Wallerstein 1979). This sort of critical analysis has been and continues to be important, but it offers only a pejorative understanding of "dependency" as a state of being.

Some feminist anthropologists have offered thoughtful critiques of the way in which autonomy, resistance, and, especially, "agency," variously defined, have been unreflectively posited as universal human desiderata even in anthropological work otherwise leery of universalist ambitions. Lila Abu-Lughod's 1990 article, "The Romance of Resistance: Tracing Transformations of Power through Bedouin women" and Saba Mahmood's 2005 book Politics of Piety: The Islamic Revival and

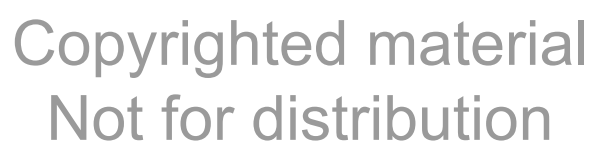


the Feminist Subject are perhaps the two most influential such critiques. They draw upon fieldwork in Islamic societies, and their arguments are grounded in cultural difference. However, though the points they make rebut one set of anthropological assumptions about autonomy and agency, they tend to reinforce another set in which assertions about human universals must necessarily be suspect, and according to the lights of which thoroughgoing exposés of hitherto-unnoticed universalisms are supremely laudable.

As a feminist and anthropologist, I feel only partial enthusiasm for these exposés. Disability theory has clarified for me why this is so. In some ways the concerns of disability theorists harmonize well with anthropological critiques of the sort described above, but in other important ways they do not. The work I find most interesting in disability theory is less concerned with the social and cultural construction of disability (though it acknowledges these dynamics) and insists instead upon dependence, debility, and disability as universal features of human experience. This makes the theory, in many ways, an awkward fit for contemporary sociocultural anthropology and in fact aligns it with a previous, now-abandoned (within anthropology) version of feminism (for a cogent rationale by one of the early architects of that abandonment, see Strathern 1987). Research and activism outside of anthropology have given rise to disability theory, which still remains less influential than it might be within the discipline (Rapp and Ginsburg 2010) and present anthropology anew with a familiar challenge about human universals. The last time anthropology faced this challenge-one presented, then, by feminism—it retreated from "master narratives" and "grand theory" in a manner the haste of which was in some ways entirely justifiable and in others deeply suspect (Hartsock 1987). Well, here we are again.

\section{DEPENDENCY}

Because Kittay's work is so central to everything I do in the rest of the book and because anthropologist readers may not have encountered her before, I want here not so much to attempt a summary of her arguments as to offer a selection of her ideas. Much of her argumentative heavy lifting is devoted to engaging with influential work in philosophy-particularly that of John Rawls - that needn't detain an anthropological audience. But she makes a series of claims about human universals that have made me fundamentally reconsider my own disciplinary disposition to reject any such claims as either underinformed or overpresumptuous about the nature of humanity in two senses: empirically, as to its real diversity on the ground, and theoretically, as to its difficulty in transcending culture-bound conceptions, such that any convincing assertion about what is universally true is inevitably tethered to conviction-shaping cultural assumptions. I wonder, now, if precisely

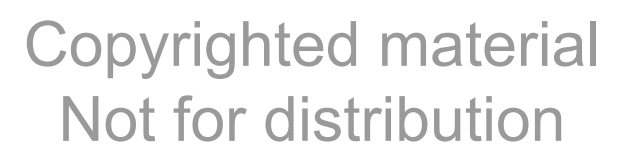


the universality of what Kittay is talking about is what has caused scholars in the Western tradition to ignore it.

What is this "it"? The dependency that is intrinsic to the human experience. All humans begin life as profoundly dependent beings, and most end life the same way; all of us also experience periods of intense dependency during the life course. This dependence, of course, implicates others: "Whether the work of caring for dependents is viewed as desirable or not ... it is work that must be done by someone" (Kittay 1999: 16). It is service work that cannot be abolished by movements of liberation. ${ }^{2}$

Kittay notes that "whether or not it is desirable to be a relational, giving self ... every society must count on certain persons adopting such a moral self" (1999: 5I). One of the arguments of the present book is that to the same extent that anthropologists come from societies (and here the key marker is not so much "Western" as "modern") that ignore this fact, such anthropologists ignore it with redoubled steadfastness in the field. They do so especially when the issue of choice-another thorny one for moderns-is involved. Speaking of dependency and dependency work, Kittay says, "Most common and interesting situations ... are those which are neither coerced ... nor voluntarily chosen" (62), and she asks,

How can the partiality exhibited in a caring relation, which might not even have been voluntarily assumed, have a moral character-especially when obligations that are not self-assumed and partiality have so often been the mark of ... actions which fail to express our moral essence? (54)

Much of living in community with others, in whatever form it takes, involves involuntary care of this kind. We do not have to look for extraordinary, heroic, or exotic examples. Your neighbors have a family bereavement; you'd just as soon not feed and walk their pets while they travel to attend the funeral, but you know money is tight in their household and they can't board the animals and they just moved into town and don't know many people to ask. They can't force you to do it, but are you going to say no? Kittay persuasively makes the case that "if [my] views are correct, then dependency relations are the paradigmatic moral relations" (7I). The claim she is making is a universal claim-something that sits easily in a philosophical work, less so when borrowed for use in an anthropological one. Nevertheless, many anthropologists will recognize that people in the communities with which they work would agree entirely with Kittay.

Anthropologists do read philosophers, but rarely feminist ones. A major recent anthropological contribution treating dependence and contemporary claims to dependence (Ferguson 2013) manages to not cite any of the feminist literature on these themes-outside of an endnote reference to Nancy Fraser and Linda

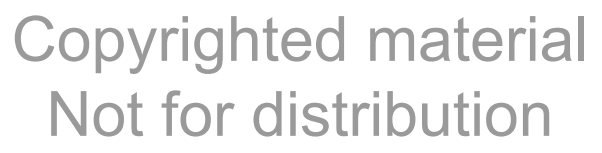


Gordon's very famous piece on dependency as a "keyword" for assaults on welfare in the US context (1994). Perhaps unsurprisingly, James Ferguson worries quite a bit about "paternalism" in his essay and seems only to have noticed how theoretically interesting dependence is when it pertains to men (2013: 233, 235), a circumstance that "makes us uneasy" (232). He concludes his piece by telling readers that "Wage labour is not the only way of contributing to the society" though as to desirable forms of dependence, "We still don't know what those are" (237) such that "we still have a great deal of work to do if we are to develop intellectual tools and political strategies adequate to these difficult times" (238). I feel pretty sure I know who the "us" and the "we" are in those sentences, but I also am quite sure they could make their lives a bit easier by reading more feminist theory and also looking again at the available evidence from their diverse field sites around the world. In her response to the piece, Oiara Bonilla goes directly to the Amazonian case she knows best, that of the Paumari of the Purus River. She says subjection can "constitute its own logic, founded on kinship and a relational conception of the person that is at the base of a social and cosmopolitical dynamic which exceeds our ideal of social well-being and autonomy" (247). Just so: in fact, with the lowland South American material I treat in this book I wish to say much the same thing, but at great length, as what Bonilla says with such economy and elegance in this single sentence.

\section{DISABILITY, INDIGENEITY, AND THE FLIGHT FROM CONTRACT}

For all that what seem to me obvious omissions in Ferguson's piece, in taking note of the startling proliferation of "declarations of dependence" among hale, hearty, working-age men in his field site in southern Africa, he is indeed on to something. The status categories "disabled" and "indigenous" share a similar recent history of explosive growth. Census reports from throughout the Americas tell us that the self-ascription of Amerindian indigeneity has grown across each decade from the r970s to the present (Salomon and Schwartz 1999). In the United States and Canada, numbers of claimants to disability assistance have grown tremendously between 1980 and today (Krieger 2003; Reaume 2008).

In both instances, these expansions are simultaneously celebrated and decried. Sometimes they are celebrated, as testaments to social progress, the outcome of successful efforts to combat the stigma that once forced people to hide their status as "disabled" or "Indian." Much more often decried, precisely as so much shameless humbug: baseless claims by large numbers of people to special statuses that when properly defined, could not be growing-only shrinking-in modern contract society. Anthropology by and large has tended toward the first reaction, as it fits well with a disciplinary commitment to the happy proliferation of difference.

\section{Copyrighted material Not for distribution}


In this book, I pay attention to the second reaction, because of its invocation of fakery-a charge to which I think anthropologists always do well to be attentive in any cultural context. We think of anthropology as the study of what people believe, but what people don't believe is at least as illuminating (this theme is expanded upon in chapters 4 and 6 of the book).

Disability theorists have been paying attention. In the United States, a considerable body of literature has grown up around case law associated with the Americans with Disabilities Act of 1990. A bill that generated unusual levels of bipartisan support at its passage, it has suffered a parade of defeats in implementation. In a perceptive analysis of the reasons why, Lennard Davis cites the anxious opinion in one judgment that the ADA creates a legally protected class that is potentially "too large" (2002: 24). Indeed, if disability theorists are right about who is formerly, actually, or potentially disabled and what kinds of people need support and protection, the category becomes universal. In practice, many people do seem to be seeking exactly such support and protection. No doubt the vogue of disability theory in late modern social science is closely related to the proliferation of disability claims in late modern societies.

Claims about disability and indigeneity come in for particular scrutiny because they are status claims, understood to be anachronistic and for that reason, in a modern contract society that makes progress an ordering principle, also anarchic. In many ways they raise the fears discussed by Douglas Baynton (1996) about encouraging "survivals" in a polity shaped by eugenicist social evolutionism. For people to cleave to status designations in a society that insists the good life can and should be built around the expansion of contract capacities is inherently confrontational.

These status claims are also subject to old-fashioned modes of critique: in the case of disability, on the grounds of "malingering," and in the case of indigeneity, on those of "passing." But the motivations of the critique are more confused in contract society than in status society. In a feudal society or a slave society, it is clear why one might wish to "pass" as aristocratic, or white, or-if the opportunity presented itself-to flee it altogether. It is equally clear why its boundaries in all of those respects were strictly patrolled. But in the story of the human story, we are only beginning to understand the brutalities (along with the inducements to loyalty) of contract society.

In its own ideal formulation, contract society is a meritocratic society in which individual people can pursue diverse goods according to their unique proclivities and capabilities. This, of course, creates abyssal, hitherto-unimaginable possibilities for failure: failures of individual imagination and failures of individual achievement. Consider the neglected upsides of status-organized societies: the life of an aristocrat was preferable to the life of a serf, but you couldn't really be fired

\section{Copyrighted material Not for distribution}


from either position. ${ }^{3}$ Being sexy or charming was surely an advantage in life, but being neither didn't necessarily mean you wouldn't find a life partner when marriages were arranged by families rather than arrived at by individuals and certainly wouldn't mean the gradual disappearance of kinship ties as you aged. You wouldn't be laid off, or left, and then — to add insult to injury — urged to reinvent yourself by "finding your passion" in the aftermath. Being not so good at things-work skills, social skills, "life skills" - is not the same kind of catastrophe in a status society that it is in a contract society.

Status societies are predicated precisely on dependence, debility, and disability. The downside to status societies, of course, is that they make these features obligatory even in circumstances where they are not present. Contract societies are predicated on independence, autonomy, and capability; the downside to contract societies is also that they make these features obligatory even where they are not present. While the "origin stories" of status societies posit a primary dependence (usually supernatural), the "origin stories" of contract societies posit a struggle for independence (both historical and ongoing) — an abolishment of despotism, monarchy, colonialism. For status societies, to reject enforced dependence, debility, and disability is to violate the cosmic order of things; for contract societies, to reject enforced independence, autonomy, and capability is to betray past, present, and future heroic struggles toward the more perfect attainment of those states (usually supposed to be "natural," either a return-to or a realization-of).

For contract societies, disabled people and indigenous people are temporary special exceptions at best; eventually, they ought to disappear: disabilities will be cured, indigenous peoples will become modern. To actively pursue entry into those special, exceptional categories, to expand them, is social treachery. People might be stuck being disabled or indigenous, but no one should expend effort to enter those categories or assert a real desire to stay in them. Davis is right when he says the real fear about disability is that the "protected class" might grow "too large." The secret anxiety here, about which modern contract society is in deep denial, is that it already does include everybody in some way.

Disability-practically and theoretically-is a critique and a betrayal of modernity, and modern society is deeply, deeply anxious about and scornful of it. Disability-abnormality rather than normality, difference rather than equality, dependence rather than independence-makes the politics of disability in the modern context very difficult to negotiate because it presents a fundamental, and transformative, challenge to modernity itself. Reading disability theory makes one look at modern Western society, and its recent history, very differently. So differently, in fact, that historical and contemporary interactions with non-Western societies start to look different, too.

\section{Copyrighted material Not for distribution}




\section{AMERICAN HEARTLANDS, NORTH AND SOUTH}

This is where the indigenous-and specifically Amerindian-part of the book comes in. I suggest that anthropology has misrecognized and misinterpreted Amerindian approaches to dependence and debility because it has viewed them through the lens of modern, Western denial and disdain. This view is most sharply the case with late nineteenth- and twentieth-century anthropology, because it was across this time that modern Western attitudes toward disability were themselves sharpening. To put it another way, Americanist anthropology was developing its own theories in this sociohistorical context just as it was systematically applying itself to the empirical study of Amerindian peoples.

The exemplary combined case here is the Ghost Dance movement and the massacre at Wounded Knee. Anthropological treatments of this phenomenon and event are emblems of the misrecognition I describe and document, and they have had a tremendous influence on historical and anthropological study throughout the Americas, as well as on popular conceptions of "Indianness" and even American Indian self-perception. Anthropologists who have read the literature on revitalization movements (and who among us has not read at least some of it?) cannot but feel a jolt of recognition, followed by dizzying defamiliarization, when they read Tobin Siebers on the myriad ways that disability is associated with narcissism: "People with disabilities, it seems, demonstrate a conspicuous resistance to reality, taking flight into an active fantasy life where their disabilities justify special privileges ... They seek revenge for their disabilities or demand compensation" (45). In an acute analytic turn, Siebers shows how the distress and anxiety of analysts, which arises from the fact that everyone is vulnerable to disablement, are consistently projected onto disabled people themselves: "the threat to the therapist's self-integration becomes an analytic tool used to think about the patient's disability" (46).

Suddenly, a tired old anthropological literature is made strange. It seems at least possible that the standard analysis of movements like the ones in the United States and Bolivia that I treat in chapters 2 and 3 -that they are the impotent revenge fantasies of fragile failures-may in fact be hostile projections by anthropologist and ethnohistorian analysts. The avowed intent of anthropology is empathy, but the spectacle of our analysands' vulnerability to politics, economics, technology, modernity, and history-forces from which we are not ourselves at all immune-perhaps instead repels us and excites our anxious disgust. We disavow these discreditable sensations in ourselves by diagnosing fantasy-ridden and revenge-bent impotence and inward-looking narcissism in our interlocutors. The pervasiveness of disability itself, of debility in the face of the world, is what we strive to repress.

The updated version of such analyses is to consider these movements to be expressive of "agency" or "resistance." This position is less pitying and patronizing, to be

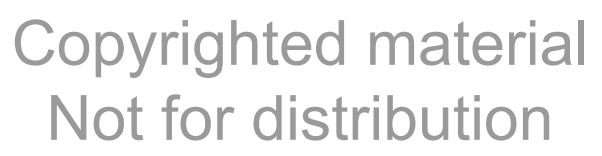


sure. On the other hand, it flies in the face of many of the observable facts. When one looks at the available historical documentation about these movements, they are replete with calls for succor, avowals of vulnerability, and dependency claims by indigenous people toward modern state agents. It's as if modern anthropologists and historians are embarrassed for nineteenth-century Indians, rushing to explain on their behalf that they didn't mean what they said-that they may have looked and sounded weak and vulnerable but that this was a ruse covering a deeper spirit of indomitability or slow-burning vengeance. Even the modern demographic rebounding of once-declining populations is entered into posthumous evidence that whatever the nineteenth-century Indians may have said about being weak and in need of help, it wasn't really true and they didn't really mean it. It takes a particular kind of habit-forged heartlessness to look at the evidence this way, one that the rest of the book tries to undo-a process that began for me long before its writing, in the lived experience of fieldwork in Isoso.

\section{ISOSO}

Isoso is home to some I5,000 people divided among about twenty-three villages (erratically successful colonization schemes to establish new villages closer to the national park territory have made this number fluctuate over the past decade). The villages are strung along the lower reaches of the Parapetí River in southeastern Bolivia, which begins in the Andean foothills and ends in swamps on the northwestern margins of the arable Chaco - the Chaco interior is far too arid for cultivation. Everyone in Isoso speaks Guaraní, the overwhelming majority as a first language, though a few villages are shared with the descendants of white settlers who began arriving at the end of the nineteenth century and who speak Spanish at home. One village, San Silvestre, is majority karai ("white"; Guaraní terms will appear in bold when first introduced in the text) and three other villages have significant karai minorities.

Isoso means "water that goes" in Guaraní, and these lower reaches of the Parapetí only run seasonally, when swollen by Andean snowmelt. During half the year, the riverbed turns into a ribbon of sand. Agriculture here depends on elaborate systems of irrigation canals to capture the seasonally available river water and distribute it to fields growing maize, manioc, sweet potatoes, and (in recent decades) rice. This irrigated agriculture has been practiced by Isoseño people for hundreds of years. Since the early twentieth century, Isoseño people have added to their seasonal patterns of agriculture and seasonal migratory wage labor at the sugar-cane harvest: first on plantations in Argentina (still called in Guaraní Mbaaporenda, "place of work") and then in plantations established in Bolivia near the lowland city of Santa Cruz de la Sierra (Karairëta, "place of white people").

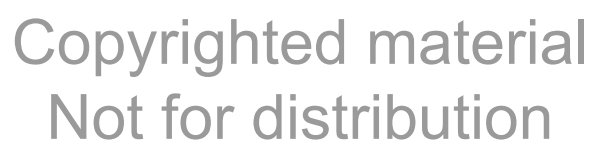


White settlers came not as farmers but as cattlemen, bringing cows and horses. More affluent Guaraní families can own significant herds, but most Guaraní families' pastoral resources are limited to goats, which travel the roads and villages in vast numbers. Many men hunt small game (armadillo, various birds) recreationally, but only a few men are serious and accomplished hunters known for going on extended outings and bagging peccary, brocket deer, and (rarely) tapir, so game meat is a delighted in but not a significant portion of the everyday diet. During two portions of the year (when the river leaves and returns), fishing does provide an important and much-looked-forward to part of the diet. Karai families tend to be marginally more affluent than Guaraní ones, but on the whole settler descendants have not been prosperous here and have adopted the Guaraní way of life with modest modifications (Spanish as a first language, more cattle, more Catholicism).

Isoso was not missionized during the colonial nor early republican era. Its first evangelical encounter was with Anglican missionaries who arrived in the 1920s, just prior to the War of the Chaco between Bolivia and Paraguay (1930-1935). While Catholicism made some inroads in the middle of the twentieth century, many more Isoseño people today are evangelical Protestants (belonging to several, often rival, sects; see Hirsch and Zarzycki 1993) than are Catholics. Every Isoseño village has a state-supported primary school and has had since the 1980 . Beginning in the I980s, first one village and by now three villages also have boarding high schools, with growing numbers of Isoseño young people completing secondary education, though still as a minority of all children. In the 1980 s a minihospital was built in Isoso's central village. It has a small operating theater and is staffed by a Bolivian doctor accompanied by an intern completing his or her medical training. Three other villages have health posts, and one village hosts a military outpost staffed by four or five soldiers: almost always local boys completing their year of mandatory military service.

Isoseño people were known in older accounts as "Chané," defined in part by their subservient relationship to other Bolivian Guaraní speakers known in older accounts as "Chiriguano." Chiriguano call themselves Ava ("men"), and they make up the vast majority of the contemporary Bolivian Guaraní people (about 50,000 of 80,000 , compared to Isoseño's 15,000; the remaining people are known as Simba). Ava used to call Isoseño Tapii (the strikethrough indicates nasalization). Isoseño people will explain that this referred to a special sort of small house they traditionally built in their agricultural fields to sleep in during the season when their crops were particularly vulnerable to birds. Ava people say this term meant "slave." I will speak more of these historical dynamics in chapter 4; for now, I will merely also note that one of the leading elite families in Isoso across several nineteenth- and early twentieth-century generations carried the surname Iyambae, which means

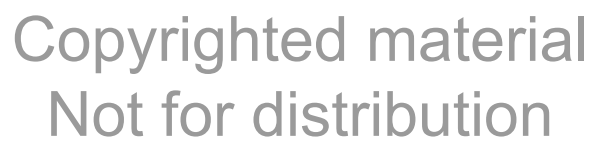




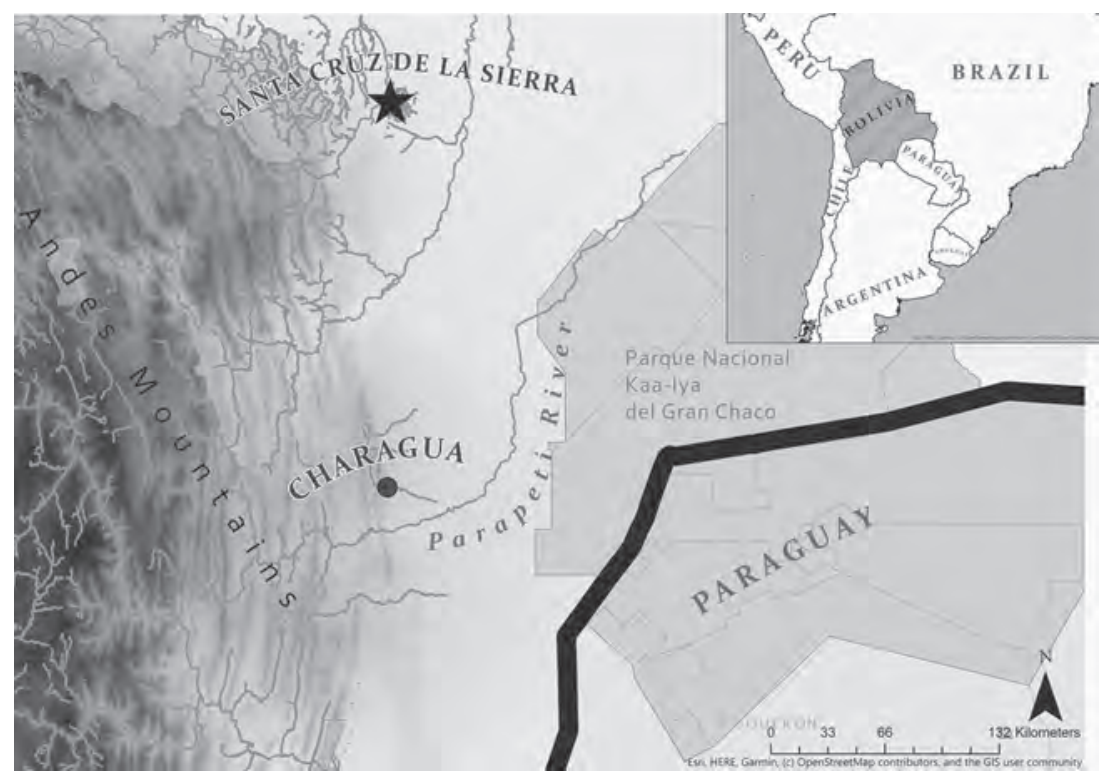

FIGURE I.I. Locations mentioned in the text: the city of Santa Cruz de la Sierra, the town of Charagua, the Parapetí River, and the Parque Nacional Kaa-Iya del Gran Chaco.

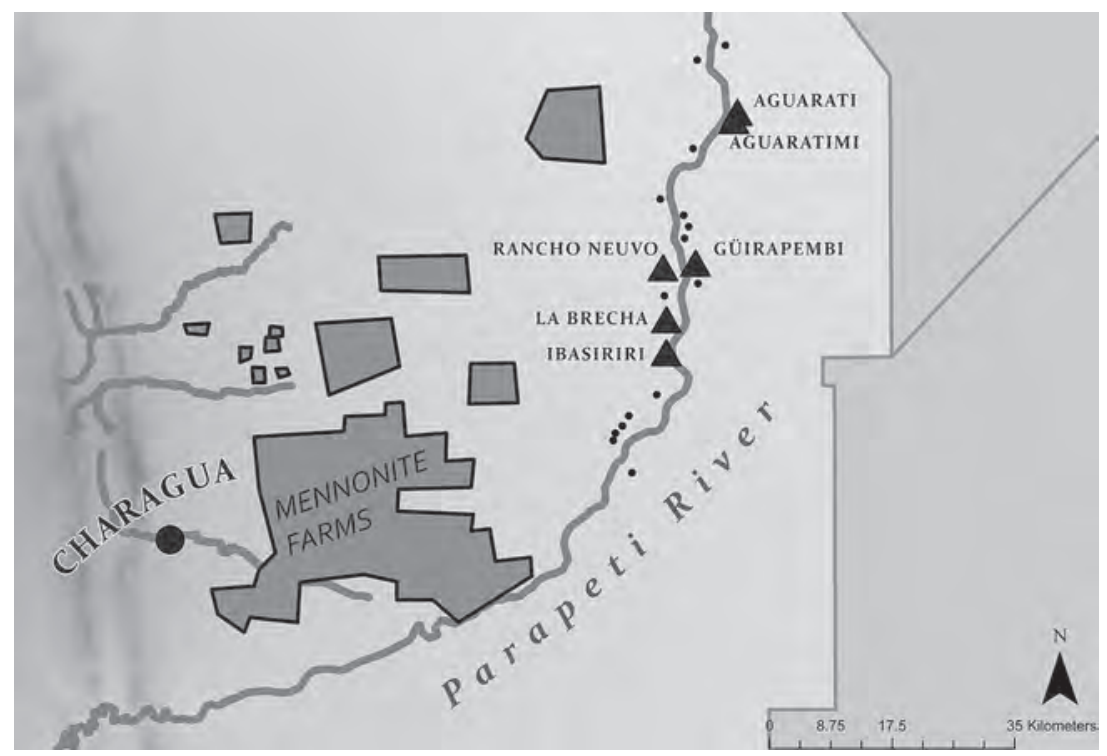

FIGURE I.2. Location of Isoseño villages along the Parapetí River. Villages mentioned in the text are labeled, and placement of Mennonite colonies (farm) indicated.

\section{Copyrighted material Not for distribution}




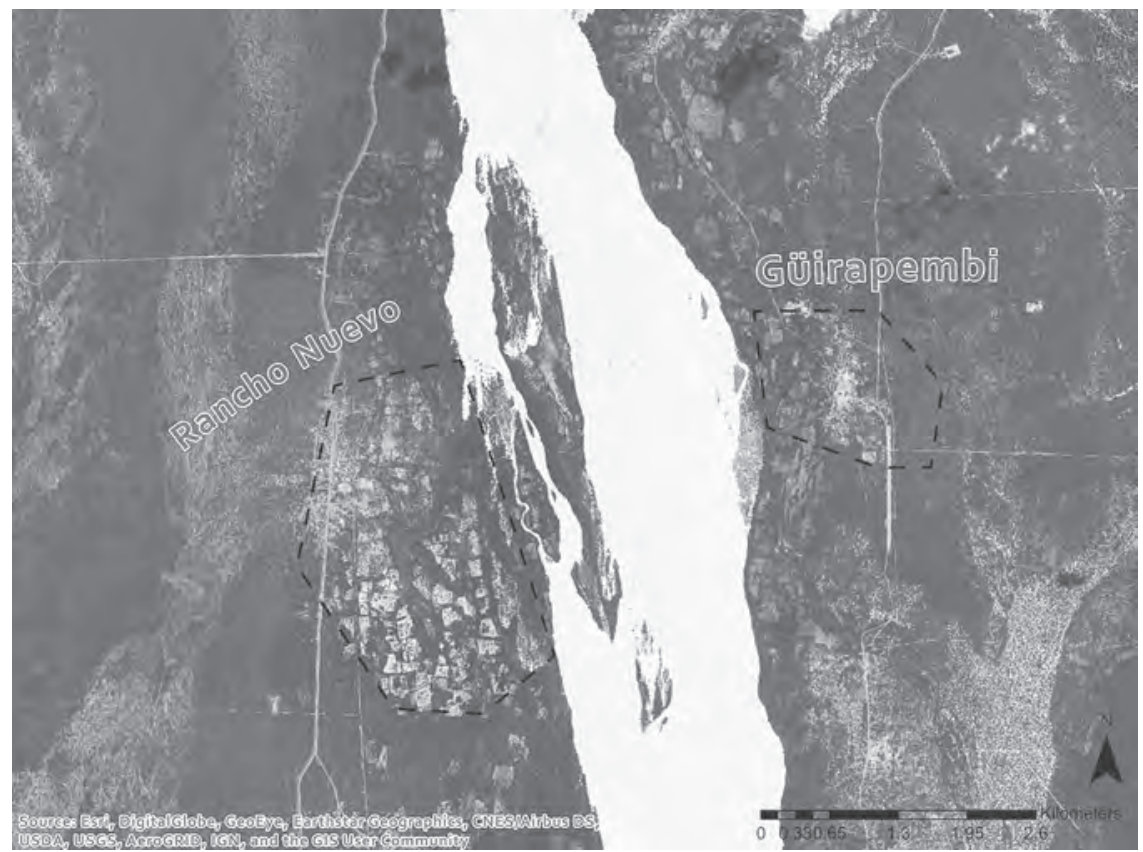

FIGURE I.3. Satellite image of the villages of Gürrapembirenda and Rancho Nuevo on facing banks of the Parapetí. The river is impassable at times because of high fastflowing current and turns into a dry ribbon of sand for a few months. For most of the year, crossing involves wading in water that is knee to waist high.

"without owner" (see Combès 2005a; Combès and Lowrey 2006; Lowrey 2003). Isoso was a particularly good place to learn about what it is to live in a status society rather than a contract one.

\section{PLAINS AND CHACO: TWO AMERICAN HEARTLANDS}

As a Chacologist (the moniker trips more easily off the tongue in Spanish, chacóloga), I have always felt a bit wistful reading analyses of Andean and Amazonian structural elegance, with their circular and quadratic geometries, their tidy moieties, their lovely formality. I can't pretend to understand all of Thomas Zuidema's arguments about Tawantinsuyu and the Inca zeke system, but I come away from them (and kindred Andeanology) with the sense of a mathematically dazzling lost world, golden khipu threads pinned across a cosmos that connects mountaintops, clouds, rivers, valley bottoms, to velvety dark night skies (Canessa 2012; Orlove et al. 2000;

\section{Copyrighted material Not for distribution}




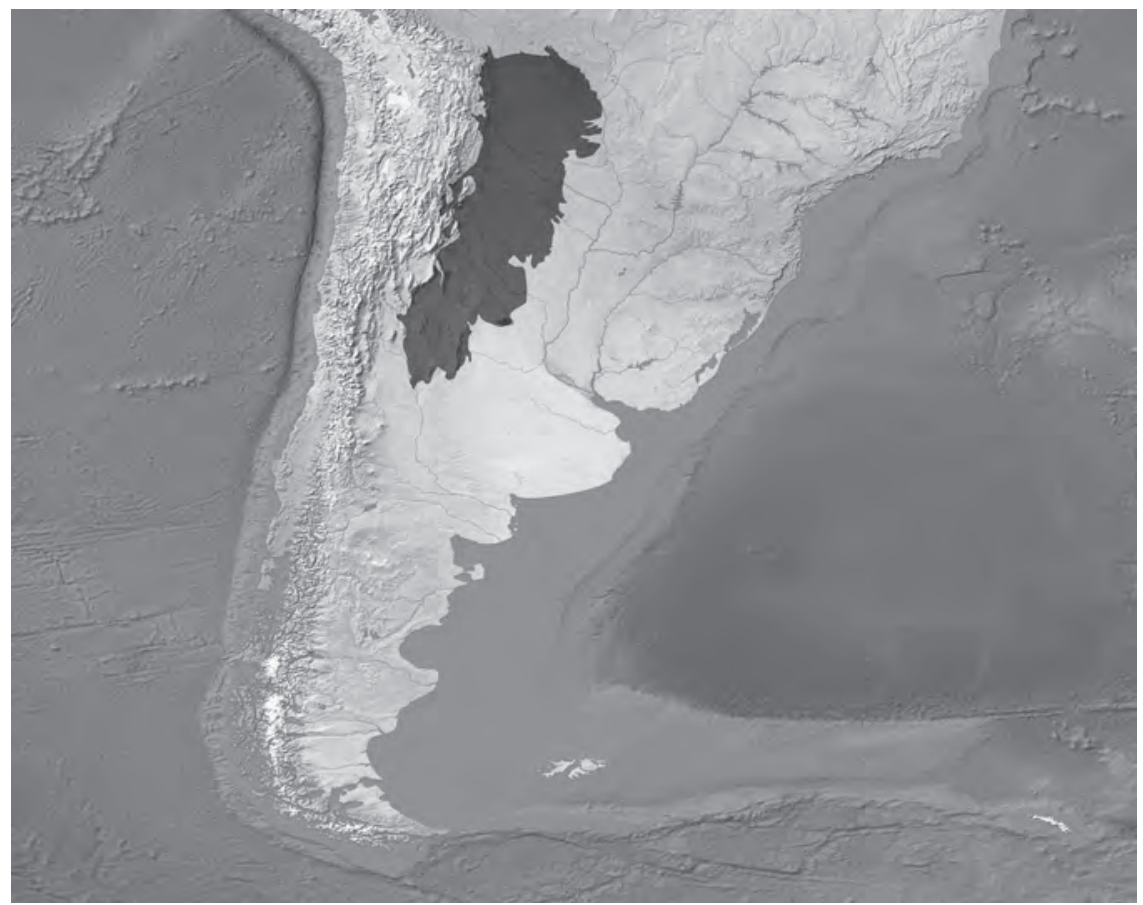

FIGURE I.4. Approximate boundaries of the Gran Chaco

Salomon 2004; Zuidema 1964, 1977, 1983). I've watched with interest and excitement the emergence of new research in Amazonia suggesting that extant moiety systems were much more elaborate in the past, populations larger, towns and agricultural terrains more extensive (Erickson 2010; Heckenberger 2008), confirming previous suggestions about the continuities between Andean and Amazonian social order and social complexity (Lévi-Strauss 1963; Turner 1984a).

The substrate in question in my own fieldwork is Chacoan sand rather than Amazonian clay or Andean stones. It's not as easily put to the ends of model making (for this argument at greater length, see Lowrey 2006a and Combès et al. 2009). Several of its peoples (Guaraní speakers on the margins, Mataco-maká, Guaycurú, Lulu-Vilela, Lengua-Maskoi, and Zamuco in the interior) are famously anarchic - canonically so in the case of the Guaraní (Clastres [1974] 1977; Viveiros de Castro 1992), quotidianly so in the case of the hunter-gatherer groups of the arid, sparsely populated, inhospitable Chaco proper. However, the societies of the Chaco are not such sports as they seem in the immediate context of the South American family. Expanding the kin diagram to include the rest of the Americas, they share

\section{Copyrighted material Not for distribution}




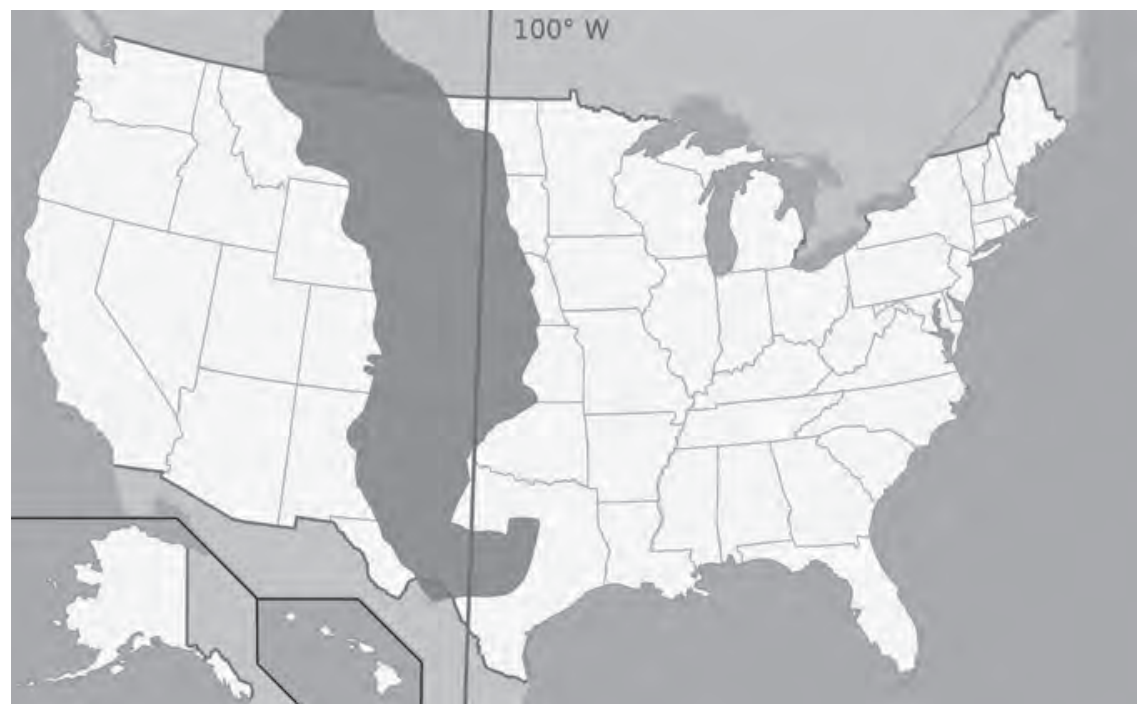

FIGURE I.5. Approximate boundaries of the Great Plains

many features and characteristics of North America Great Plains societies-among them, the same lonesome swagger and the same secret coziness.

Since 2005 , my professional home has been a public university on the Canadian Prairies: the University of Alberta. The parallels between the North American Great Plains (or, as the same geographic region is termed in Canada, the Prairies) and the South American Gran Chaco have long been noted by other observers, and the similarities have been insistently present to my consciousness as I have traveled back and forth for many years now between Alberta, Canada, and the Bolivian and Paraguayan Chaco. While in each case there is much argument as to their limiting margins, their core zones are clear (Rossum and Lavin 2000). These two arid interior regions, each located to the east of a great mountain range and to the west of a great wave of European settlement, were both colonized initially more by cows than people and both have been ecologically pitiless obstacles to settler ambitions. Both have been theaters for an eighteenth- and nineteenth-century florescence of native "horse complexes" - the adoption by some aboriginal groups of an animal introduced by Europeans to much-mythologized native ends (Albers 1993; Albers and James 1986; Métraux 1946a; Mitchell 2015; Nichols 1939; Schindler 1985). Both have given rise to canonical images of "wild Indians" and especially of markedly masculine "Braves," what French ethnohistorian Thierry Saignes described as "indios de abajo" (1980). Both have been home to enormous, nearly feudal land

\section{Copyrighted material Not for distribution}


holdings; the King Ranch in Texas compares to the Casado holdings in Paraguay. Estimates of the size of each vary, but hover close to the same number: $1,300,000$ square kilometers in area.

What on first sight struck me as the incongruously Midwestern farms of Mennonites plonked down in the heartland of South America are the grafting onto both landscapes, Northern and Southern American, of a "German Russian" cultivation style brought over from the breadbasket of the Ukraine. The religiously separatist diaspora of Mennonites in the Chaco (present also in the Prairies and Plains, and often involving travel between these sites) has parallels in that of the Mormons in Utah (and Alberta, as it happens). Chapter 7, the final chapter, examines the Mennonite case.

But to begin: that the great nineteenth century Ghost Dance movement and the associated massacre at Wounded Knee in 1890 should have a doppelgänger in a prophetic movement in the Bolivian Chaco-and associated massacre at a place called Kuruyuki, in 1892 -is an eerie coincidence that makes sense from a dependency logic of everything being related after all. But you may not be as much of a witchyminded conspiracy theorist as I am, yet. I have six chapters left to bring you round.

\section{Copyrighted material Not for distribution}

